\title{
Secretory Leukocyte Protease Inhibitor: A Human Saliva Protein Exhibiting Anti-Human Immunodeficiency Virus 1 Activity In Vitro
}

Tessie B. McNeely, ${ }^{\star}$ Marian Dealy, ${ }^{\star}$ David J. Dripps, ${ }^{\ddagger}$ Jan M. Orenstein, ${ }^{\boldsymbol{5}}$ Stephen P. Eisenberg, ${ }^{\star}$ and Sharon M. Wahl ${ }^{\star}$

${ }^{*}$ Laboratory of Immunology, National Institute of Dental Research, National Institutes of Health, Bethesda, Maryland 20892; ${ }^{\ddagger}$ Synergen

Inc., Boulder, Colorado 80301; and ${ }^{\S}$ George Washington University School of Medicine, Washington DC 20037

\begin{abstract}
Infection of adherent primary monocytes with $\mathrm{HIV}-\mathbf{1}_{\mathrm{Ba}-\mathrm{L}}$ is significantly suppressed in the presence of human saliva. By reverse transcriptase ( $R T$ ) levels, saliva, although present for only $1 \mathrm{~h}$ during monocyte viral exposure, inhibited HIV1 infectivity for 3 wk after infection, whereas human plasma and synovial fluid failed to inhibit HIV-1 infectivity. Antiviral activity was identified in the saliva soluble fraction, and to determine the factor ( $\mathrm{s}$ ) responsible, individual saliva proteins were examined. Of those proteins examined, only secretory leukocyte protease inhibitor (SLPI) was found to possess anti-HIV-1 activity at physiological concentrations. SLPI anti-HIV-1 activity was dose dependent, with maximal inhibition at $1-10 \mu \mathrm{g} / \mathrm{ml}$ ( $>90 \%$ inhibition of RT activity). SLPI also partially inhibited HIV-1 $1_{\text {IIIB }}$ infection in proliferating human $T$ cells. SLPI appears to target a host cell-associated molecule, since no interaction with viral proteins could be demonstrated. However, SLPI anti-HIV-1 activity was not due to direct interaction with or downregulation of the CD4 antigen. Partial depletion of SLPI in whole saliva resulted in decreased anti-HIV-1 activity of saliva. These data indicate that SLPI has antiretroviral activity and may contribute to the important antiviral activity of saliva associated with the infrequent oral transmission of HIV-1. (J. Clin. Invest. 1995. 96:456-464.) Key words: monocytes - lymphocytes $\cdot$ SLPI $・$ retrovirus $・$ saliva
\end{abstract}

\section{Introduction}

The virtual absence of oral transmission of HIV-1 (1-4) and reports of antiviral activity in the saliva of both healthy (5-9) and HIV-1-infected (7) individuals suggest the presence of a factor or factors in saliva that can inhibit HIV-1 infection. Although the source(s) and mechanism for this activity remain

A portion of these results was presented at the 2nd National Conference on Human Retroviruses and Related Infections sponsored by the American Society for Microbiology in Washington, D.C. on 29 January through 2 February 1995 and the Keysone Symposia on Molecular and Cellular Biology, HIV Pathogenesis in Keystone, CO on 17-23 April 1995.

Address correspondence to Tessie B. McNeely, Building 30, Room 329, National Institute of Dental Research, National Institutes of Health, 30 Convent Drive, MSC 4352, Bethesda, MD 20892-4352. Phone: 301496-5796; FAX: 301-402-1064.

Received for publication 28 September 1994 and accepted in revised form 3 March 1995.

The Journal of Clinical Investigation, Inc.

Volume 96, July 1995, 456-464 poorly understood, aggregation of HIV-1 by large molecular weight molecules (mucins, etc.) in the saliva has been implicated $(8,10,11)$ and is consistent with the HIV-1 particle aggregation and entrapment by saliva observed ultrastructurally on small pore filters $(12,13)$. Although virus aggregation by saliva mucins may play a role in the anti-HIV-1 effect of saliva, additional evidence for a soluble anti-HIV-1 activity has been reported $(8,11,13)$. Moreover, significant anti-HIV-1 activity may be found in parotid gland secretions, which are purely serous and contain no mucins and do not appear to aggregate HIV-1 particles $(13,14)$. Therefore, it has been postulated that there are at least two mechanisms present in saliva that may contribute to antiviral activity in vitro. One of these is due to physical entrapment of the viral particles; the other is due to inhibitory activity by an unknown soluble factor(s).

Identification and characterization of the natural anti-HIV1 agent(s) present in saliva may have significant implications. The anti-HIV-1 activity present in saliva does not appear to be due to a broad-spectrum antiviral agent, since some infectious viruses, such as cytomegalovirus, may be cultured from human saliva $(6,12)$. The anti-HIV-1 activity appears to be specific to saliva because other body fluids, such as cerebrospinal fluid and urine (10), are devoid of anti-HIV-1 activity. The examination of saliva collected from individual salivary glands precludes the possibility of the presence of a large number of blood cells, bacteria, or food particles in the secretions and therefore their contributing to this inhibitory activity $(6,7,13)$.

To define this natural HIV-1 inhibitor, saliva secretion fractions and purified salivary proteins were examined for their ability to inhibit HIV-1 infection in an in vitro assay system using adherent human monocytes. Primary monocytes serve as host cells of HIV-1 in vivo, contribute to the pathology of AIDS, and are important targets for antiviral therapy (15-19). These cells were infected with HIV-1 in the presence or absence of saliva and/or its constituents. Using this assay system, we have identified secretory leukocyte protease inhibitor (SLPI) ${ }^{1}$ as a saliva-derived factor possessing significant anti-HIV-1 activity. We demonstrate here that the antiinfectivity action of SLPI does not appear to be at the level of HIV-1 binding, nor does SLPI inhibit reverse transcriptase (RT) or HIV-1 protease. Rather, its target may be a host cell-associated molecule. Based on its potent antiviral activity, SLPI, a $12-\mathrm{kD}$ serine protease

1. Abbreviations used in this paper: EDC, $N$-ethyl- $N^{\prime}$-(3-diethylaminopropyl)-carbodiimide; HNE, human neutrophil elastase; HRP, histidine-rich peptide; IL-2R, IL-2 receptor; GSH, glutathione; NHS, Nhydroxysuccinimide; PLSD, protected least significant difference; PRP, proline-rich peptide; RT, reverse transcriptase; SLPI, secretory leukocyte protease inhibitor; $\mathrm{sCD} 4$, soluble $\mathrm{CD} 4$; $^{\mathrm{T}} \mathrm{CID}_{50}$, tissue culture infectious dose. 
inhibitor (20), may play a role in preventing oral infection and/ or transmission of HIV-1.

\section{Methods}

Monocyte isolation and culture. PBMC, obtained by leukapheresis (Department of Transfusion Medicine, National Institutes of Health), were separated from granulocytes by fractionation on Ficoll-Hypaque (Pharmacia Diagnostics AB, Stockholm, Sweden). PBMC were then separated by countercurrent centrifugal elutriation, as previously described (21). By this method, $85-95 \%$ pure monocytes are obtained (21). Monocytes were diluted to $2-4 \times 10^{6}$ cells per $\mathrm{ml}$ in DME (BioWhittaker, Walkersville, MD) with $2 \mathrm{mM}$ L-glutamine and $50 \mu \mathrm{g} / \mathrm{ml}$ gentamicin and plated at $2 \mathrm{ml}$ per well in glass two-well chamber slides (Nunc, Inc., Naperville, IL). After adherence (overnight, $37^{\circ} \mathrm{C}, 5 \%$ $\mathrm{CO}_{2}$ ), $10 \%$ human $\mathrm{AB}^{-}$serum (Advanced Biotechnologies Inc., Columbia, MD) was added to the culture medium. Cells were cultured from 10-14 $\mathrm{d}$ before being infected with HIV-1.

Reagents assayed for anti-HIV-l activity. Whole human saliva (unstimulated) was collected into polypropylene tubes and centrifuged at $3,000 \mathrm{~g}$ for $15 \mathrm{~min}$. For sterilization, saliva was passed through a 0.22 $\mu \mathrm{m}$ Millex-GV filter (Millipore Products Div., Bedford, MA). Submandibular secretions were collected using sterile collection devices $(6,7)$ and were size fractionated by gel filtration chromatography (D. Hay, Forsyth Dental Center, Boston, MA), using TrisAcryl Plus GF2000-M (Sigma Chemical Co., St. Louis, MO) in $100 \mathrm{mM}$ ammonium bicarbonate, $0.1 \%$ chloroform. Fractions were lyophilized, reconstituted to the original starting volume of whole saliva with PBS, and assayed for anti-HIV-1 activity. Individual saliva-derived proteins included two closely related acidic proline-rich proteins, PRP-1 and PIF, statherin (gifts from D. Hay), purified histidine-rich peptides 3 and 5 (HRP-3 and HRP-5), partially purified lysozyme (Sigma Chemical Co. and gift from J. Pollock, Stony Brook, NY), lactoferrin (Sigma Chemical Co.), and cystatin (Sigma Chemical Co. and gift from T. Lah, Ljubljana, Slovenia). Synovial fluid was collected aseptically from the joints of patients with rheumatoid arthritis (22).

Recombinant SLPI (23) was $>98 \%$ pure and contained $<0.74$ endotoxin units per mg of SLPI. Recombinant SLPI and native SLPI are equivalent based on several criteria. In particular, they have the same amino-terminal sequence $\left(\mathrm{H}_{2}-\mathrm{N}-\mathrm{Ser}-\mathrm{Gly}\right.$-Lys-Ser-Phe- . . .) due to the activity of processing enzymes in Escherichia coli that remove the encoded methionine residue from the amino terminus. In addition, both recombinant and natural SLPI are not glycosylated.

HIV-1 infection of monocytes. HIV-1 $1_{\mathrm{Ba}-\mathrm{L}}$ (Advanced Biotechnologies Inc., Columbia, MD), propagated in primary human monocyte/ macrophages, was diluted to $10^{4} \mathrm{TCID}_{50} / \mathrm{ml}$ of DME and combined in a 1:1 ratio with human saliva, serum, synovial fluid, or purified saliva proteins. The virus was incubated in the absence or presence of candidate inhibitory factors for $30 \mathrm{~min}$ at room temperature followed by $30 \mathrm{~min}$ at $37^{\circ} \mathrm{C}, 5 \% \mathrm{CO}_{2}$. In some experiments, saliva was prefiltered through a sterile $0.22-\mu \mathrm{m}$ filter before addition to virus. Alternatively, the virus/ unfiltered saliva suspension was incubated for $1 \mathrm{~h}$ and then filtered (postfiltered) through a $0.22-\mu \mathrm{m}$ filter, before being added to cells. The virus \pm inhibitor was added to adherent monocytes in two-well chamber slides, $400 \mu \mathrm{l}$ per well. After $60 \mathrm{~min}$ at $37^{\circ} \mathrm{C}$ in $5 \% \mathrm{CO}_{2}$, unbound virus was removed by washing cells three times with $2 \mathrm{ml}$ of PBS. Cells were refed with $2 \mathrm{ml}$ of DME containing $10 \%$ human $\mathrm{AB}^{-}$serum, 50 $\mu \mathrm{g} / \mathrm{ml}$ gentamicin, and $2 \mathrm{mM}$ L-glutamine (DME complete medium). In some experiments, monocytes were preincubated with candidate inhibitor for $1 \mathrm{~h}$ at $37^{\circ} \mathrm{C}$, washed three times with PBS, and incubated with $\mathrm{HIV}-1_{\mathrm{Ba}-\mathrm{L}}$ alone for $1 \mathrm{~h}$ at $37^{\circ} \mathrm{C}$, and unbound virus was removed by washing cells three times with PBS. In all cases, every 3-4 d, 0.5 $\mathrm{ml}$ of medium was removed for virus assay and replaced with fresh complete medium. Cells were cultured for 3-3.5 wk after infection. When the infection time course was complete, slides were stained with Diff-Quik (Baxter Healthcare Corp., Miami, FL) to monitor whether equivalent numbers of monocytes remained in each well. Cell culture conditions and infection typically did not affect monocyte viability. However, data are reported only from experiments in which equivalent cell numbers were documented.

Isolation of T cells and infection with HIV-1 $1_{M I B}$. Primary T cells were separated from B cells and monocytes by countercurrent centrifugal elutriation (21). T cells were cultured at $10^{6}$ cells per ml in RPMI 1640 (BioWhittaker), 10\% FCS (BioWhittaker), $2 \mathrm{mM} \mathrm{L}$-glutamine, and 50 $\mu \mathrm{g} / \mathrm{ml}$ gentamicin (RPMI complete medium), containing $50 \mu \mathrm{M} \beta$ mercaptoethanol and $5 \mu \mathrm{g} / \mathrm{ml} \mathrm{Con} \mathrm{A.} \mathrm{After} 72 \mathrm{~h}$ at $37^{\circ} \mathrm{C}, 5 \% \mathrm{CO}_{2}$, the proliferating cells were infected with HIV- $1_{\mathrm{IIB}}$ (Advanced Biotechnologies, Inc.), a T cell isolate ( $\mathrm{HIV}-1_{\mathrm{Ba}-\mathrm{L}}$ does not infect $\mathrm{T}$ cells efficiently in vitro, therefore a T cell tropic strain must be used). HIV-1 $1_{\text {IIв }}$ was first preincubated with SLPI or with medium only, for $1 \mathrm{~h}$ at $37^{\circ} \mathrm{C}$, and the virus \pm SLPI $\left(2 \times 10^{3}\right.$ TCID $_{50}$ of HIV-1 $\left.1_{\text {IIIB }}\right)$ was used to infect T cells at $10^{7}$ cells per $\mathrm{ml}$ in RPMI. After $1 \mathrm{~h}$ at $37^{\circ} \mathrm{C}, 5 \% \mathrm{CO}_{2}$, T cells were pelleted and washed with PBS three times. Cells were resuspended in RPMI complete medium containing $20 \mathrm{U} / \mathrm{ml} \mathrm{IL}-2$ (Collaborative Biomedical Products, Bedford, MA) at $10^{6}$ cells per ml in 48-well plates, and cell culture supernatants were sampled for the presence of RT activity or p24 antigen every 3-4 d.

Monitoring of viral infection. The RT assay was performed as described (24). RT values of the virus were unaffected by short-term (6h) exposure of the virus to SLPI (RT values, HIV plus SLPI [100 $\mu \mathrm{g}$ / $\mathrm{ml}]=25 \times 10^{4} \pm 1.1 \times 10^{4} \mathrm{cpm}$, and HIV alone $=23 \times 10^{4} \pm 1.4$ $\times 10^{4} \mathrm{cpm}$ ), indicating that SLPI did not inhibit the RT assay. p24 was assayed using the p24 core profile ELISA kit from Dupont (Wilmington, DE) (19). For electron microscopy, supernatants from adherent cells (infected in the presence or absence of SLPI) were removed and cells were fixed with $2.5 \%$ glutaraldehyde in PBS. After fixation, cells were harvested with a rubber policeman, transferred to 1.5 -ml microfuge tubes, and pelleted at $4,500 \mathrm{~g}$ for $2 \mathrm{~min}$. After gelling in agar, the cells were postfixed in $1 \% \mathrm{OsO}_{4}$, block stained with saturated uranyl acetate in 50\% ethanol, dehydrated in graded ethanol and propylene oxide, and embedded in Spurr's plastic. Thin sections were stained with uranyl acetate and lead citrate and examined in a Zeiss EM $10 \mathrm{~A}^{\mathrm{R}}$ operating at $60 \mathrm{kV}(25)$.

Labeling of cell surface antigens. Single-cell suspensions $(50 \mu \mathrm{l})$ of monocytes $\left(10^{7} / \mathrm{ml}\right.$ ) in PBS (with $0.1 \% \mathrm{NaN}_{3}$ ) were incubated at $4^{\circ} \mathrm{C}$ for $30 \mathrm{~min}$ with FITC-conjugated monoclonal antibodies to the following cell surface antigens: IL-2 receptor (IL-2R), CD14, and CD4 (Becton Dickinson Monoclonal Center Inc., Mountain View, CA), or the control antibody, mouse FITC-IgG (Simultest; Becton Dickinson). Cells were stained in the presence of $10 \%$ human $\mathrm{AB}^{-}$serum to prevent nonspecific binding. After staining, cells were washed two times with cold PBS and resuspended in $0.5 \mathrm{ml}$ of $2 \%$ paraformaldehyde. Cells were analyzed by flow cytometry with a FACScan (Becton Dickinson) (25).

Proliferation assays. The continuous $\mathrm{T}$ cell line $\mathrm{H} 9$ was used to assess the potential cytostatic/cytotoxic effect of saliva and SLPI on cell proliferation. H9 cells were combined with whole saliva (diluted as for anti-HIV-1 assay) for $1 \mathrm{~h}$, washed three times with PBS, and plated at $10^{5}$ cells per $200 \mu \mathrm{l}$ per well in 96-well plates. Alternatively, SLPI $(100 \mu \mathrm{g} / \mathrm{ml})$ was added to $\mathrm{H} 9$ cells and left for the remainder of the proliferation time course $(3 \mathrm{~d})$. Cells were pulsed with $5 \mu \mathrm{l}$ of 50 $\mu \mathrm{Ci} / \mathrm{ml}\left[{ }^{3} \mathrm{H}\right]$ thymidine (thymidine 5 '-triphosphate, $20.3 \mathrm{Ci} / \mathrm{mmol}$; New England Nuclear, Boston, MA) $18 \mathrm{~h}$ before harvesting and assaying $\left[{ }^{3} \mathrm{H}\right]$ thymidine incorporation. No cytostatic/cytotoxic effects of either saliva or SLPI were observed using this assay.

Depletion of SLPI from saliva. A SLPI affinity column was prepared by chemically coupling $\sim 2 \mathrm{mg}$ of goat polyclonal anti-SLPI antibody to protein A agarose followed by chemical blocking of unreacted protein A sites, using the ImmunoPure IgG Orientation kit from Pierce (Rockford, IL) according to the manufacturer's directions. Whole saliva (4 $\mathrm{ml}$ ) was diluted 1:3 in PBS and centrifuged for $15 \mathrm{~min}$ at 3,000 $\mathrm{g}$, and the supernatant was divided into two aliquots. One aliquot was applied to the SLPI affinity column; the other was applied to a control column 
(protein A agarose prepared as the above column but containing no anti-SLPI antibody). After sample loading, columns were rotated end over end for $1 \mathrm{~h}$ at $4^{\circ} \mathrm{C}$, and then the saliva was eluted. To determine how much SLPI was removed from the saliva samples, saliva was supplemented with $2 \times 10^{4} \mathrm{cpm}{ }^{125} \mathrm{I}$-SLPI $\left(10^{7} \mathrm{cpm} / \mu \mathrm{g}\right)$, radiolabeled using $\mathrm{Na}^{125}$ I (ICN Biomedicals, Inc., Irvine, CA) and IODOGEN (Pierce), according to manufacturer's directions. Samples of saliva from each column were assayed for gamma emission to calculate the amount of SLPI removed by passage through the column. Additionally, saliva samples from each column were subjected to Western analysis using goat polyclonal anti-SLPI antibody. By counts per minute, only $\sim 50 \%$ of SLPI was removed using the SLPI affinity column, and this percent was not increased appreciably by reapplication to the regenerated affinity column. The limited depletion of SLPI from saliva was most likely due to minor cleavage of SLPI by enzymes in the saliva. Aside from specific removal of SLPI, all other saliva proteins remained essentially equal in concentration in samples from the anti-SLPI column as compared with samples from the control column, as assayed by Coomassie blue staining of saliva samples analyzed on $12 \%$ SDS-polyacrylamide gels. Control saliva and saliva partially depleted of SLPI were sterile filtered, diluted to give a 1:10 final dilution of the starting saliva, and used in HIV-1 infection of monocytes as previously described. Loss of anti-HIV-1 activity by the partially depleted saliva was calculated as followed, assuming negligible counts in the negative control sample (sample not infected with HIV-1): [ $\left.\left(\mathrm{RT}_{\text {depleted saliva }} / \mathrm{RT}_{\text {positive control }}\right) \times 100\right]-\left[\left(\mathrm{RT}_{\text {whole }}\right.\right.$ saliva $\left./ \mathrm{RT}_{\text {positive control }}\right) \times 100$ ], in which $\mathrm{RT}$ is the reverse transcriptase value in counts per minute.

Direct binding measurements to SLPI. SLPI binding to various proteins was assayed by surface plasmon resonance detection using a biospecific interaction analysis (BIAcore) instrument (Pharmacia LKB Biotechnology Inc., Piscataway, NJ) (26-27). SLPI was immobilized on the CM5 sensor chip surface using the amine coupling kit containing $\mathrm{N}$-hydroxysuccinimide (NHS), $\mathrm{N}$-ethyl- $\mathrm{N}^{\prime}$-(3-diethylaminopropyl)carbodiimide (EDC), and ethanolamine hydrochloride, pH 8.5 (Pharmacia LKB Biotechnology Inc.). Briefly, the carboxylated dextran matrix of the chip was activated with EDC/NHS for $7 \mathrm{~min}$ followed by

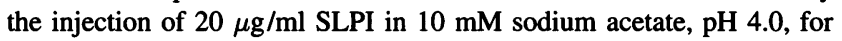
$10 \mathrm{~min}$. Unreacted NHS-ester groups were displaced by the injection of ethanolamine for $6 \mathrm{~min}$. To assess the binding activity of the immobilized SLPI, 100 nM human neutrophil elastase (Calbiochem Corp., San Diego, CA) was injected at a flow rate of $10 \mu \mathrm{l} / \mathrm{min}$ in $10 \mathrm{mM}$ sodium Hepes, pH 7.0, $150 \mathrm{mM} \mathrm{NaCl}$, and $3.4 \mathrm{mM}$ EDTA. HIV-1 protease (IIIB), soluble (s)CD4, gp160 (IIIB), and gp120 (IIIB) (all recombinant proteins were from American BioTechnologies, Inc., Cambridge, MA) were likewise used at concentrations of $100 \mathrm{nM}$. Recombinant gp120 was also immobilized on the sensor chip surface, and sCD4 (20 $\mu \mathrm{g} / \mathrm{ml}$ ) binding was measured using published methods (28).

Statistical analysis. Statistical analysis was performed using Stat View software (Abacus Concepts, Inc., Berkeley, CA) and choosing the one-way ANOVA and Fisher's protected least significant difference (PLSD) values for comparison of data pairs.

\section{Results}

Inhibition of monocyte infection after saliva treatment of HIV1. As an initial investigation of the selective HIV-1-inhibiting activity of saliva, HIV-1 was incubated with saliva for $1 \mathrm{~h}$, sterile filtered through a $0.22-\mu \mathrm{m}$ pore filter, and added to adherent monocyte monolayers. After $1 \mathrm{~h}$, both virus and saliva were washed off, and the progression of infection was monitored. As shown in Fig. 1, the exposure of virus to saliva results in essentially complete suppression of infection of the monocytes, in contrast with the level of infection induced by untreated virus. Since filtration of saliva-containing virus samples can lead to removal of some virus due to virus trapping, with resul-

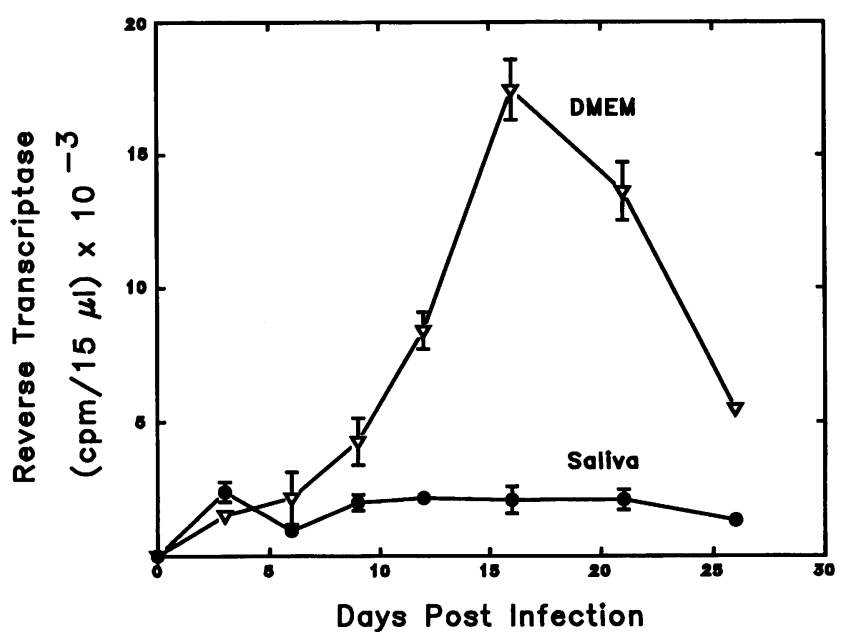

Figure 1. Effect of saliva on HIV-1 infection of human monocytes. Virus was incubated with saliva or DME for $1 \mathrm{~h}$. Virus suspensions were filtered and combined with adherent monocytes for $1 \mathrm{~h}$. Cells were then washed free of unbound virus and cultured for over 3 wk. Cell supernatants were removed at 3-4-d intervals, and virus RT activity was measured. Data are the mean $\pm \mathrm{SE}$ from one experiment repeated in duplicate three times with similar results.

tant artificially reduced HIV-1 infection (8, 11-13), additional experiments were conducted in which the saliva was prefiltered before it was added to the virus. Prefiltered saliva incubated with virus and not filtered again still significantly reduced monocyte infection, demonstrating the presence of a soluble factor in saliva with anti-HIV-1 activity (Fig. $2 A$ ). For comparison, two other protein-rich body fluids, plasma and synovial fluid, were added to HIV-1, incubated, and added to the monocytes in parallel with filtered saliva. Whereas the saliva inhibited HIV1 by $85-95 \%$, no inhibitory activity was observed in either plasma or synovial fluid (Fig. $2 B$ ), indicating that a unique antiviral molecule(s) is present in saliva.

Investigation of saliva components for anti-HIV-1 activity. To investigate the properties of the soluble factor(s) responsible for the HIV-1-inhibiting activity of saliva, $20 \mathrm{ml}$ of stimulated submandibular saliva was subjected to fractionation by gel filtration. The low molecular weight (between 10 and $14 \mathrm{kD}$ ) protein-enriched fractions were found to contain the antiviral activity, as measured by their ability to inhibit HIV-1 infection of monocytes (data not shown).

In parallel experiments, purified and recombinant components of whole saliva associated with these fractions were individually examined directly for antiviral activity. Representatives of the four major classes of saliva proteins were assayed: the proline-rich proteins (PRP-1 and PIF), the histatins (HRP-3 and HRP-5), statherin, and cystatin, some of which have antifungal as well as antibacterial activities (29). Several host defense proteins found in saliva, including lysozyme, lactoferrin, and SLPI, were also assayed. When assayed at levels exceeding physiological concentrations, PRP, statherin, and HRP had minimal or no anti-HIV-1 activity (Table I). Lysozyme and lactoferrin exhibited apparent anti-HIV-1 activity only at concentrations $>10$ times physiologic concentrations. The small cationic antiprotease cystatin exhibited significant anti-HIV-1 activity ( $>90 \%$ inhibition of RT values as compared with controls) 


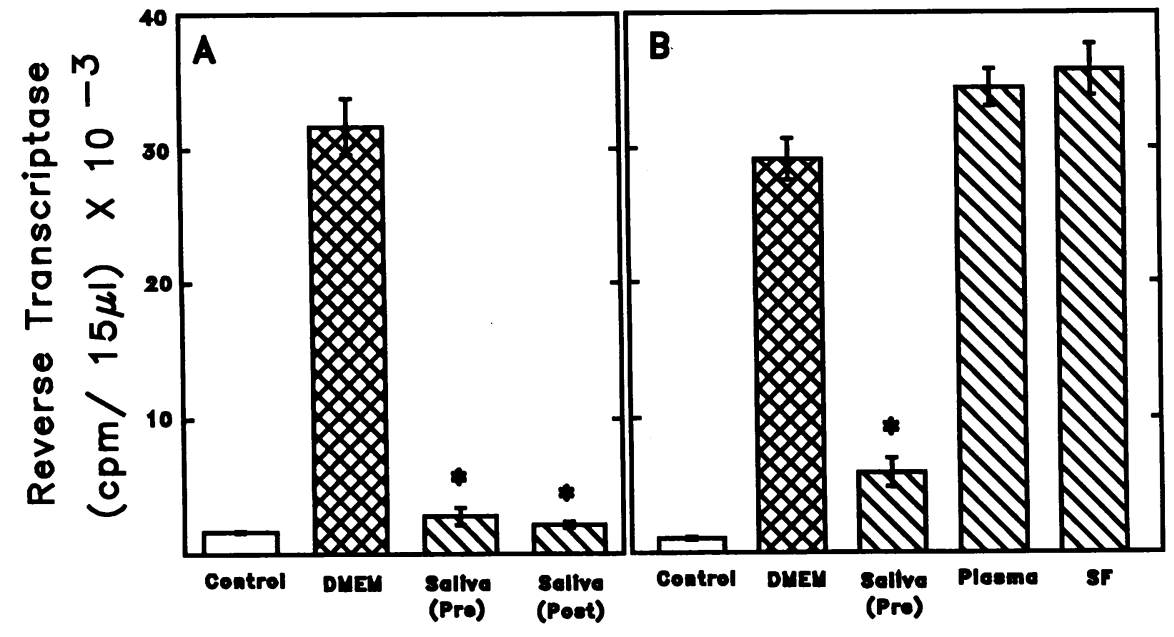

Figure 2. Effect of prefiltered saliva on HIV1 infection in human monocytes. $(A)$ Virus was incubated for $1 \mathrm{~h}$ with filtered saliva (Pre), or DME, or unfiltered saliva (virus/ saliva was then filtered before addition to monocytes [Post]). Virus suspension was then added to monocytes for $1 \mathrm{~h}$ and washed away, and cells were cultured for $3 \mathrm{wk}$. Results are RT values at peak infection (day 16). Control samples had no HIV-1 added. (B) Virus was incubated with either prefiltered saliva (Pre), unfiltered plasma, unfiltered synovial fluid $(S F)$, or DME. After 1 $h$, each virus suspension was added to monocytes for $1 \mathrm{~h}$, and cells were washed and cultured for $3 \mathrm{wk}$. Control samples had no HIV-1 added. * Values significantly different from DME values, with $>95 \%$ confidence (Fisher's PLSD). when assayed at levels exceeding saliva concentrations by $\sim$ 10-20-fold (Table I). However, when cystatin was assayed at physiologic concentrations $(1 \mu \mathrm{g} / \mathrm{ml})$, only moderate antiHIV-1 activity was observed ( $20 \%$ inhibition of RT values as compared with controls). A second low molecular weight cationic protease inhibitor found in saliva, SLPI, was also tested for its ability to inhibit HIV-1 infection of monocytes. In contrast to the other salivary proteins, SLPI possessed significant antiHIV-1 activity at physiologic concentrations (Table I).

SLPI inhibition of HIV-1 in monocytes. As shown in Fig. 3 , recombinant SLPI was able to duplicate the anti-HIV-1 activity of whole saliva based on RT assays, and a single exposure to SLPI at the time of coculture of monocytes and HIV-1 suppressed infection for nearly 3 wk of culture. Viral p24 antigen was measured to confirm RT assay results, and that assay gave results similar to RT assays (Fig. $3 B$ ). To confirm the RT and

Table I. Effect of Saliva Components on HIV-1 Infection of Monocytes

\begin{tabular}{lccc}
\hline $\begin{array}{c}\text { Saliva } \\
\text { component }\end{array}$ & $\begin{array}{c}\text { Concentration } \\
\text { in saliva }\end{array}$ & $\begin{array}{c}\text { Concentration } \\
\text { in assay }\end{array}$ & $\mathrm{IC}_{90^{*}}$ \\
\hline & $\mu g / m l$ & $\mu g / m l$ & $\mu g / m l$ \\
PRP-1 & 100 & $25-500$ & $\mathrm{NA}^{\ddagger}$ \\
PIF & 100 & $25-500$ & $\mathrm{NA}$ \\
Statherin & 100 & $25-500$ & $\mathrm{NA}$ \\
HRP-3 & $3-10$ & $15-300$ & $\mathrm{NA}$ \\
HRP-5 & $3-10$ & $15-300$ & $\mathrm{NA}$ \\
Cystatin & $1-2$ & $25-500$ & $25-35$ \\
Lysozyme & $8-16$ & $25-500$ & $400-500$ \\
Lactoferrin & $6-30$ & $25-500$ & $400-500$ \\
SLPI & $4-24$ & $1-10$ & 1 \\
\end{tabular}

* Concentration(s) of saliva component required during HIV-1 infection of monocytes to inhibit RT values quantitated at $16-20 \mathrm{~d}$ after infection by $>90 \%$, as compared with control values in which only DME was preincubated with HIV-1 and present during infection. Data are determinations from one experiment, which was performed two or more times with similar results. Standard errors for RT values ranged from 10 to $15 \%$. ${ }^{\ddagger} \mathrm{NA}$, inhibition not achieved at any concentration tested. p24 results morphologically, ultrastructural analysis of HIV-1infected cells was performed. Adherent monocytes were infected with HIV-1 in the presence or absence of SLPI (1-10 $\mu \mathrm{g} / \mathrm{ml}$ ) and cultured for 16-23 d. Infected cells were analyzed for the presence of viral particles and the number of particles per infected cell. Cultures infected in the presence of SLPI contained no, or significantly fewer, infected monocytes than cultures infected in the absence of SLPI (data not shown). In one representative experiment, cultures incubated with HIV-1 alone had 10 times more infected cells at the peak of infection than those incubated with HIV-1 plus $10 \mu \mathrm{g} / \mathrm{ml} \mathrm{SLPI.} \mathrm{The} \mathrm{few}$ monocytes infected in the presence of SLPI also exhibited fewer intracellular viral particles than those infected in the absence of SLPI. In experiments examined, the electron microscopy results paralleled the values obtained with RT (or p24) assays (25). Virus particles were found in normal intramonocytic vacuoles for cultures infected in the presence or absence of SLPI, indicating that SLPI was not merely altering intracellular viral distribution and thereby masking viral replication. In a SLPI anti-HIV-1 dose-response assay, significant inhibitory activity was measured at SLPI concentrations from 0.1 to $25 \mu \mathrm{g} / \mathrm{ml}$ (Fig. $4 A$ ).

SLPI inhibition of HIV-1 in T cells. SLPI also exhibited partial anti-HIV-1 activity in proliferating T cells, with a doseresponse curve similar to that observed in adherent monocytes (Fig. $4 \mathrm{~B}$ ). In these experiments, SLPI was added to the T cells only during the initial viral exposure and was washed off before cell culture. Repetitive administration of SLPI to these proliferating cell populations would likely maintain viral suppression.

Examination of the anti-HIV-1 activity of SLPI. To rule out the possibility that the anti-HIV-1 activity of SLPI was due to nonspecific effects of the protein on cells, SLPI cytotoxicity was examined. Using the assay described in Methods, no cytotoxic/cytostatic effects of SLPI on proliferating H9 cells were observed (data not shown).

To determine whether SLPI was altering viral infection of monocytes nonspecifically by activating or inactivating the cells, the following experiment was conducted. Monocytes in suspension culture were incubated at $37^{\circ} \mathrm{C}, 5 \% \mathrm{CO}_{2}$ overnight in DME complete medium with either LPS, SLPI, or a combination of the two. The following day, cells were stained with 


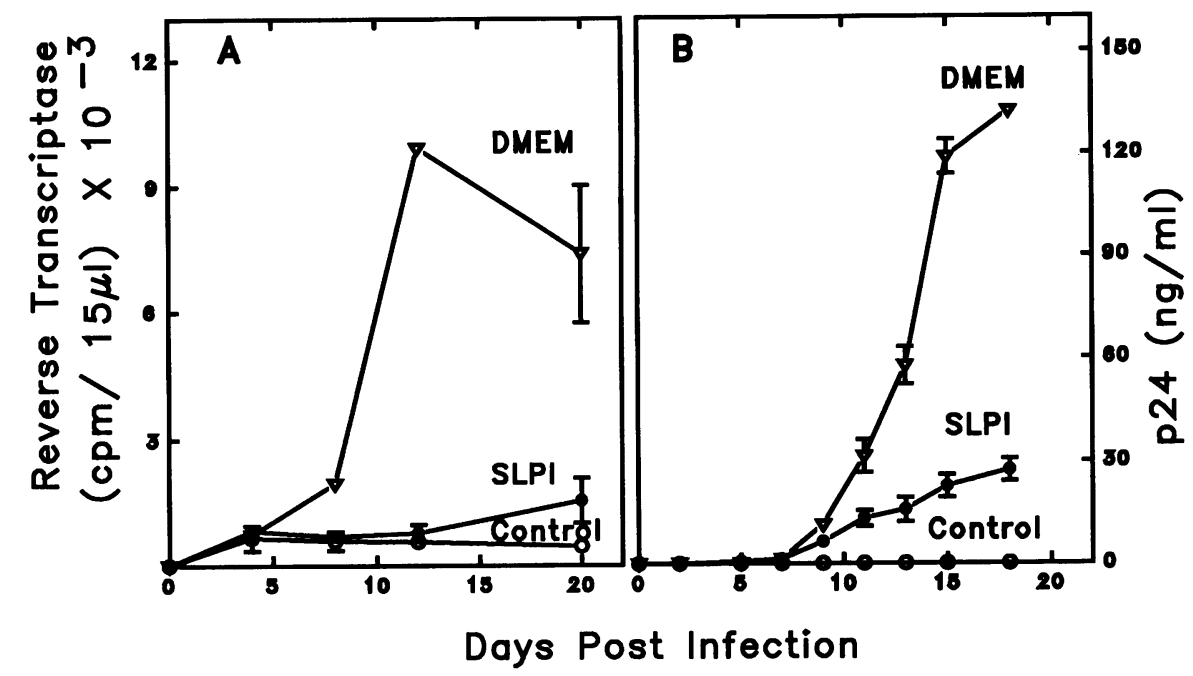

Figure 3. Effect of SLPI on HIV-1 infection of human monocytes. Virus was incubated with SLPI or DME for $1 \mathrm{~h}$. Virus suspension was added to monocytes for $1 \mathrm{~h}$, and cells were washed three times with PBS and cultured for $\sim 3 \mathrm{wk}$. Culture supernatant was removed at 3-4-d intervals for assay of RT. Control samples had no HIV-1 added. Points represent mean $\pm \mathrm{SE}$ of one experiment repeated six times with similar results. $(A)$ Results of RT assay; $(B)$ results of p24 assay for an experiment similar to but independent of $A$. fluorescent antibodies to cell surface antigens and analyzed using a FACScan. As shown in Table II, control cells incubated overnight were essentially negative for the presence of the IL$2 \mathrm{R}$ (a monocyte marker for cell activation) (18), 30-40\% were positive for CD4 (the HIV-1 receptor), and the majority of cells expressed CD14 (a constitutively expressed monocyte marker). Cells incubated overnight with LPS exhibited increased staining for the IL-2R, with little change in levels of CD4 and CD14 expression. Cells incubated with $1-100 \mu \mathrm{g} / \mathrm{ml} \mathrm{SLPI} \mathrm{were} \mathrm{phe-}$ notypically similar to the control cells, whereas cells coincubated with SLPI and LPS resembled those incubated with LPS only. Thus, SLPI does not activate cells as LPS does; nor does it prevent cell activation by LPS as monitored phenotypically. Additionally, SLPI does not downregulate expression of the HIV-1 receptor, CD4. Taken together, these data suggest that SLPI does not transduce an activation signal or inhibit CD4 expression as a component of its primary mechanism of antiviral activity.

Examination of SLPI's role in saliva anti-HIV-1 activity. To establish whether native SLPI in saliva was contributing to the anti-HIV-1 activity of saliva, whole saliva was partially depleted of SLPI and compared with a control whole saliva sample (both were prepared as described in Methods). These intact and SLPI-deficient saliva samples were incubated with HIV-1 and monocytes infected as described previously. Approximately $50 \%$ of the SLPI could be removed from the sample when passaged through the anti-SLPI column, as monitored by radiolabeled SLPI and by Western analysis (Fig. $5 B$ ). However, by Coomassie blue staining of proteins analyzed on SDSPAGE, all other saliva proteins remained equivalent in concentration to those in the intact control sample (Fig. $5 \mathrm{C}$ ). This selective removal of SLPI decreased the anti-HIV-1 activity of the saliva sample compared with the control sample (Fig. 5 $A$ ). The anti-HIV-1 activity of saliva partially depleted of SLPI was reduced by $48 \%$ compared with intact saliva when used at a dilution of 1:10 during monocyte infection, consistent with the $50 \%$ depletion of the protein. Thus, although other saliva constituents may also contribute to the antiviral activity of saliva, it is clear that SLPI accounts for a major portion of the anti-HIV-1 activity in intact saliva.

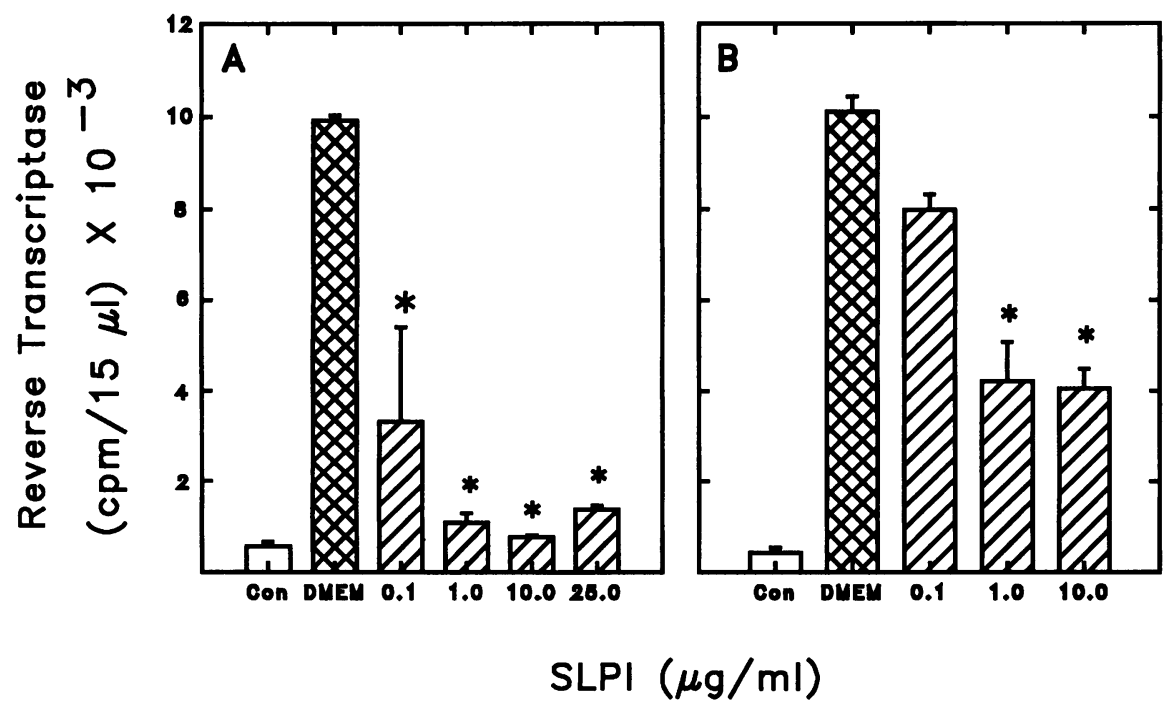

Figure 4. Effect of SLPI on HIV-1 infection of human monocytes or T cells. $(A)$ Virus was incubated with DME or increasing concentrations of SLPI for $1 \mathrm{~h}$. Virus solutions were then added to adherent monocytes for $1 \mathrm{~h}$, and cells were washed free of unbound virus and cultured for $3 \mathrm{wk}$. RT values shown are at peak infection. Control samples (Con) had no HIV-1 added. $(B)$ Virus was incubated with DME or increasing concentrations of SLPI for $1 \mathrm{~h}$. Virus solutions were then added to proliferating $T$ cells for $1 \mathrm{~h}$, and cells were washed free of unbound virus and cultured for $2 \mathrm{wk}$. RT values shown are at peak infection. Control samples had no HIV1 added. Points represent mean $\pm S E$ of one experiment done in duplicate two or more times with similar results. * Values statistically different from DME values, with $>$ 95\% confidence (Fisher's PLSD). 
Table II. FACS Analysis of SLPI's Effect on Monocyte Cell Surface Antigens

\begin{tabular}{lccc}
\hline & \multicolumn{3}{c}{ Cell surface antigens (percent } \\
positive)
\end{tabular}

Elutriated monocytes were incubated overnight with DME alone (Control cells), or DME containing LPS, SLPI, or both. The cells were stained with FITC-labeled antibodies to the antigens listed and analyzed using a FACScan. Percent positive cells was determined by subtracting the percent positive cells stained with FITC-labeled mouse IgG (Simultest) (ranging from 1 to $3 \%$ of total) from the percent positive cells stained with FITC-labeled specific antibody. Data shown are a representative data set from an experiment repeated three times.

Examination of the SLPI-target molecule interaction. The question of whether SLPI influences viral infection by influencing viral activity or the host cells was investigated. SLPI ( 10 $\mu \mathrm{g} / \mathrm{ml}$ ) was preincubated with adherent monocytes for $1 \mathrm{~h}$ and then washed away before the 1-h viral addition. Significantly, SLPI exhibited equivalent antiviral activity under these conditions, as in experiments in which SLPI was preincubated with virus before addition to monocytes ( $>90 \%$ inhibition of RT values assayed at 16-20 d after infection), suggesting that its target resides at the level of the host cell rather than the virus. Under the conditions of this experiment, it was determined by SLPI ELISA (R \& D Systems, Inc., Minneapolis, MN) that only $2-20 \mathrm{ng} / \mathrm{ml}$ of SLPI remained free in the culture supernatant after aspiration of the culture supernatant and washing the cells three times with PBS. In a second set of experiments, highly concentrated virus stock $\left(\mathrm{TCID}_{50}=0.5 \times 10^{7.50} / \mathrm{ml}\right.$ ) was incubated with $5 \mu \mathrm{g} / \mathrm{ml}$ SLPI or DME only, for $1 \mathrm{~h}$ at $37^{\circ} \mathrm{C}$. The virus was then diluted $\left(\mathrm{TCID}_{50}=6.3 \times 10^{4} / \mathrm{ml}\right)$ and used to infect monocytes as usual. The final concentration of SLPI with the virus during infection was $0.02 \mu \mathrm{g} / \mathrm{ml}$, which is below the level at which SLPI significantly inhibits HIV-1 infectivity. The virus preincubated with SLPI and then diluted gave the same level of infection $\left(\mathrm{RT}=12.8 \times 10^{4} \pm 1.4 \times 10^{4}\right.$ cpm at day 21) as the virus preincubated with medium alone $\left(\mathrm{RT}=13.8 \times 10^{4} \pm 4.9 \times 10^{4} \mathrm{cpm}\right)$. It thus appeared that SLPI's target is cell, not virus, associated.

To extend this analysis and investigate potential binding sites on the virus and cells, the BIAcore system was used to measure the binding of SLPI to specific candidate molecule targets on the virus or host cell. When the viral proteins HIV1 protease, gp160, and gp120 (all at $100 \mathrm{nM}$ ) were tested, no specific binding of any of these viral constituents to immobilized SLPI was observed (Fig. 6). Additionally, direct binding of $100 \mathrm{nM}$ sCD4 to anti-HIV-1 was not detected using this method, consistent with the lack of detectable change in CD4 expression on the monocytes after treatment with SLPI. Under

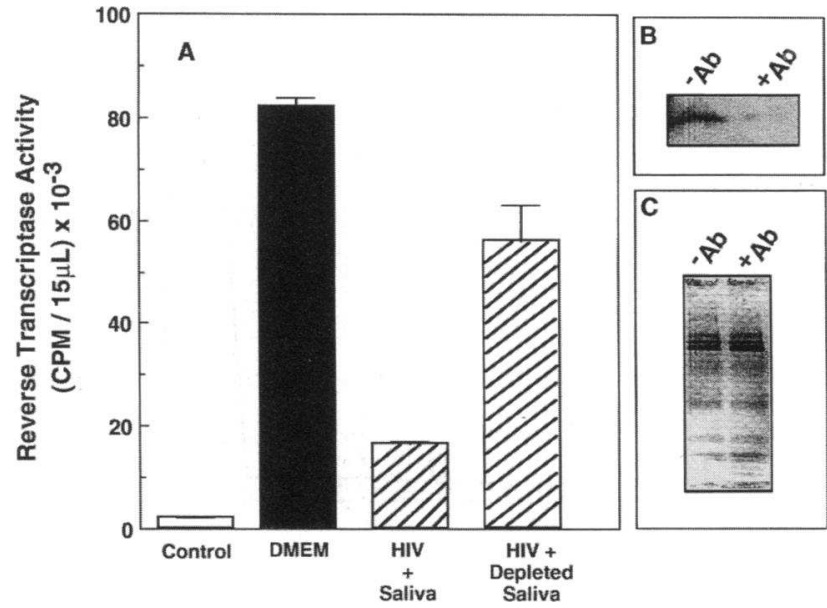

Figure 5. Effect of partial removal of SLPI from saliva on the antiHIV-1 activity of saliva. Human saliva was partially depleted of native SLPI using goat polyclonal anti-SLPI antibodies, as described in Methods. Saliva from a single donor was chromatographed using either an anti-SLPI affinity column $(+A b)$, or a control column (containing no anti-SLPI antibody) $(-A b)$. Removal of SLPI was determined by observing a $50 \%$ decrease in a trace amount of ${ }^{125}$ I-SLPI included in the saliva samples and by Western analysis of the resulting saliva samples $(C)$. Selective removal of SLPI did not result in a change in concentration of the other saliva proteins, as determined by Coomassie blue staining of proteins in both the control saliva sample (left lane) and depleted saliva sample (right lane) electrophoresed on a $12 \%$ polyacrylamide gel $(B)$. However, the anti-HIV-1 activity of the partially depleted saliva sample was reduced by $48 \%$, as compared with the control saliva sample $(A)$. Monocytes were infected either with HIV-1 that had been preincubated for $1 \mathrm{~h}$ at $37^{\circ} \mathrm{C}$ with medium alone $(D M E M)$, with control saliva, or with saliva partially depleted of SLPI, or they were not infected (Control).

identical conditions, however, immobilized SLPI was capable of binding human neutrophil elastase (Fig. 6), reflecting its biological activity in solution (20). In control experiments, to ensure that the viral recombinant proteins maintained biological binding activity, the binding activities of the recombinant SCD4 and gp120 were examined using the BIAcore system. The observed binding of sCD4 to immobilized gp120 (data not shown) was consistent with published results (28).

Therefore, the evidence indicates that the SLPI anti-HIV1 activity is most likely due to an interaction with a host cell molecule and not a direct interaction with virus particles. Importantly, the host cell molecule does not appear to be CD4

\section{Discussion}

The virtual absence of HIV-1 spread via oral transmission suggests the presence of an important natural anti-HIV-1 agent(s) in the oral cavity (1-4). Indeed, even the isolation of intact virus from saliva of AIDS patients is exceedingly rare (3031 ). Although nonspecific antiviral activity may be found in other body fluids $(14,32,33)$, antiviral activity specific for HIV-1 has thus far been described only in salivary gland secretions. In this study we demonstrate that the anti-HIV-1 activity of whole saliva can be attributed, at least in part, to the $12-\mathrm{kD}$ polypeptide, SLPI, found in saliva at microgram concentrations 

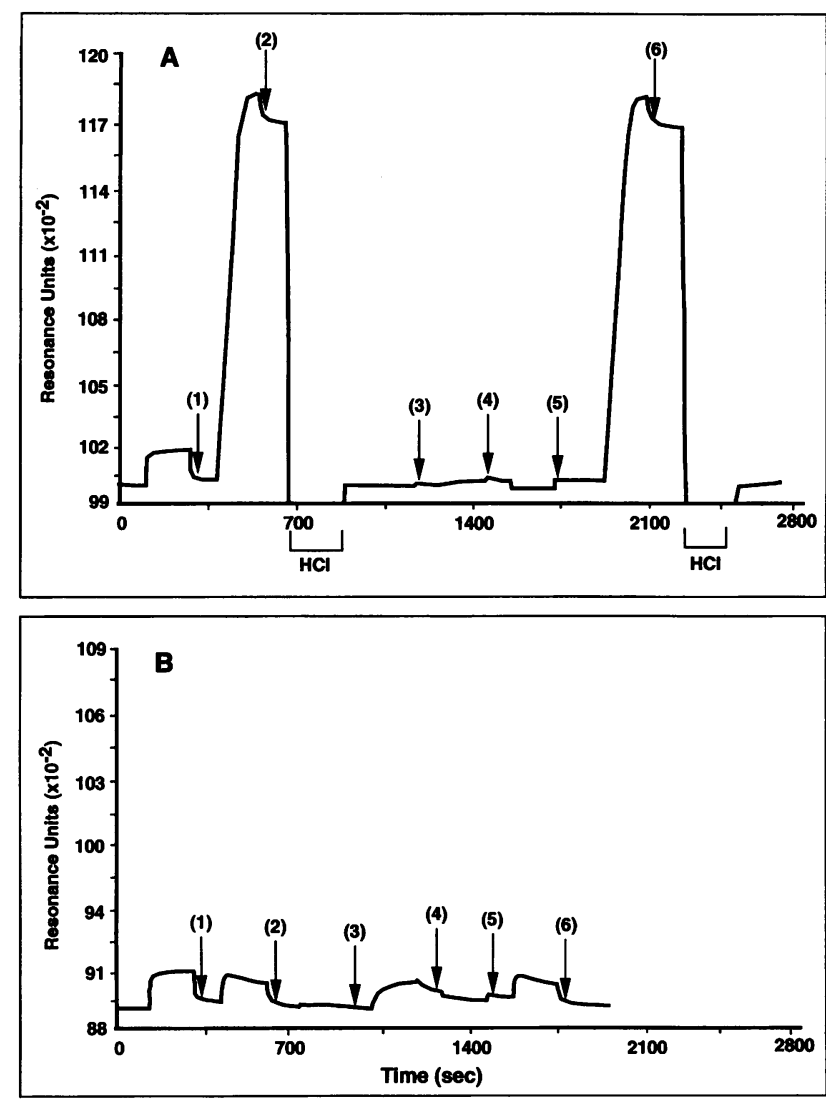

Figure 6. Biosensor-derived binding curves for the injection of (1) HIV1 protease, (2) human neutrophil elastase (HNE), (3) sCD4, (4) gp120, $(5)$ gp 160, and (6) HNE (as indicated), to either ( $A$ ) SLPI coupled to the biosensor surface or $(B)$ a blank biosensor surface. Injected proteins were at $100 \mathrm{nM}$. SLPI was immobilized at a level of 1,160 resonance units, or $1.16 \mu \mathrm{g} / \mathrm{mm}^{2}$, as described in Methods. The arrows indicate points on the binding curves used to quantitate each binding event. 10 $\mathrm{mM} \mathrm{HCl}$ was used to regenerate the SLPI surface after HNE binding. Relative binding values in resonance units for each protein are as follows: $(A)$ HIV protease, 43; HNE, 1,880; sCD4, 14; gp120, 39; gp160, 31; HNE, 1,880. (B) HIV protease, 57; HNE, 38; sCD4, 5; gp120, 99; gp160, 67; HNE, 33.

(34). Depletion of SLPI from intact saliva resulted in a corresponding loss of antiviral activity, confirming that SLPI represents a major portion of the anti-HIV-1 activity in saliva.

SLPI is a serine protease inhibitor produced by salivary glands and is found in saliva and other mucous secretions. The protein consists of two homologous cysteine-rich domains and exhibits inhibitory activity against neutrophil elastase, chymotrypsin, trypsin, and cathepsin $G(20,35)$. By site-directed mutagenesis, residue Leu-72 has been shown to be the active site for SLPI's protease inhibitory activity (22). It is this antiprotease activity that led to preclinical and clinical studies using SLPI in emphysema and cystic fibrosis patients $(36,37)$, but this is the first evidence that SLPI has antiviral activity.

SLPI was found to inhibit HIV-1 infectivity of monocytes and $T$ lymphocytes in a dose-dependent manner, with significant inhibition observed at a concentration as low as $0.1 \mu \mathrm{g} / \mathrm{ml}(8$ $\mathrm{nM}$ ) and maximally at $1-10 \mu \mathrm{g} / \mathrm{ml}$, well within the physiologic range. As demonstrated by both RT and p24 levels, a single 1- $\mathrm{h}$ exposure to SLPI during infection was sufficient to suppress virus production for several weeks. Ultrastructural analysis confirmed RT and p24 assay results, demonstrating that virus was not being routed to and accumulating in an abnormal compartment within the cells, such that it could not be assayed in the culture supernatant.

Based on the profound antiviral activity of SLPI, efforts were directed at defining its mechanism of action and whether its target resided at the level of the virus or the cell being infected. Several lines of evidence suggest that SLPI interacts with cell-associated molecules to effect its antiviral actions. First, that SLPI need not interact directly with virus particles to exhibit antiviral activity was demonstrated by results showing that preincubation of monocytes with SLPI alone, before addition of virus, was sufficient to inhibit HIV-1 infectivity. The ability to pretreat cells with SLPI and induce inhibition of HIV1 infection implicated the cells, rather than the virus, as the target of SLPI's action. Second, in related experiments, when concentrated HIV-1 was coincubated with high levels of SLPI that were then diluted to noninhibitory levels before infection, no suppression or inhibition of the virus was observed. Third, SLPI was not found to bind specifically to the viral surface proteins gp160 or gp120, nor to HIV-1 protease.

Experiments to identify the cell-associated molecules, or targets, for SLPI's anti-HIV-1 activity suggest that specific binding of SLPI to SCD4 does not occur; nor does SLPI downregulate the CD4 antigen on monocytes. Although we cannot rule out the possibility that SLPI forms a complex with CD4 and an as yet unidentified molecule, our data suggest other cell-associated interactions may be involved. It has been well documented that HIV-1 entry into host cells requires more than viral binding to cell CD4 antigen (38-41). Evidence has been presented suggesting involvement of a cell surface enzyme(s) in the infection of CD4 ${ }^{+}$cells by HIV-1. The enzyme may be a protease $(40,42-44)$ or protein disulfide-isomerase (45), and it is possible that SLPI competes for binding with the virus for a cell surface enzyme(s). A subpopulation of PBMC express both cathepsin $G$ and human neutrophil elastase (46), which are susceptible to SLPI activity. Interestingly, cathepsin G, a target enzyme of SLPI (20), has been identified as a cell surface protease on U937 cells that interacts specifically with the V3 loop of HIV-1 gp120 (47). However, the anti-HIV-1 activity of SLPI is not a general property of proteinase inhibitors, since plasma, which contains high levels of several proteinase inhibitors (e.g., alpha-1 protease inhibitor and alpha-2 macroglobulin), does not exhibit anti-HIV-1 activity. SLPI is positively charged and may bind to the surface of cells nonspecifically via electrostatic interactions. However, it is unlikely that this could lead to inhibition of HIV, since only anionic compounds have been reported to prevent HIV's binding to cells (e.g., dextran sulfate, heparin, etc.) $(48,49)$, and moreover, SLPI's interaction with monocytes reflects specific, high affinity binding (McNeely, T. B., manuscript in preparation). In addition, lysozyme is also highly positively charged and does not exhibit the potent antiviral activity of SLPI (Table I). Therefore, SLPI most likely exhibits its antiviral activity by binding specifically to a host cell molecule(s) other than the HIV-1 receptor, CD4.

Administration of SLPI to humans or sheep has been shown to cause an increase in glutathione (GSH) levels in pulmonary lining fluid (50), presumably mediated by host cells, and furthermore, it has been well established that intracellular GSH 
can inhibit the growth of HIV-1 by blocking proviral transcription and possibly other processes required for viral propagation $(51,52)$. Whether this pathway plays any role in SLPI's antiviral activity in vitro is currently unknown. Studies in progress will provide insight as to whether SLPI's anti-HIV-1 activity is the result of inducing higher intracellular GSH levels in human monocytes, SLPI antiprotease activity, or some as yet to be identified mechanism.

In the current studies, SLPI was shown, for the first time, to contribute to the anti-HIV-1 activity of human saliva in vitro; thus, it may play an important role in the unique antiHIV-1 infectivity activity of human saliva. It is currently unknown whether SLPI functions as an anti-HIV-1 agent in other tissues of the body, although SLPI is generally present at higher concentrations in tissues associated with lower rates of transmission of HIV-1 $(34,53-55)$. If an inverse correlation exists between levels of SLPI and the risk or rate of HIV-1 transmission, exogenously administered SLPI may afford protection against this lethal virus.

\section{Acknowledgments}

The authors would like to thank Dr. Randall Wagner and Dr. Robert Thompson for helpful discussions during the preparation of this manuscript; Beverly Handelman and Janice Allen for expert technical assistance; Christopher Smith (Synergen, Inc., Boulder, $\mathrm{CO}$ ) for goat antiSLPI antibody; Dr. D. Hay for saliva gel filtration; and Dr. J. Pollock and Dr. T. Lah for saliva proteins.

This work was supported by a Collaborative Research and Development Agreement (CRADA) between the National Institute of Dental Research (NIDR) and Synergen, Inc., and in part by a contract from the NIDR (DE 12585 to J.M. Orenstein).

\section{References}

1. Freidland, G. H., B. R. Saltzman, M. F. Rogers, P. A. Kahl, M. L. Lesser, M. M. Meyers, and R. S. Klein. 1986. Lack of household transmission of HTLVIII infection. N. Engl. J. Med. 314:344-349.

2. Gerberding, J. L., C. E. Bryant-LeBlanc, K. Nelson, A. R. Moss, D. Osmond, H. F. Chambers, J. R. Carlson, W. L. Drew, J. A. Levy, and M. A. Sand. 1987. Risk of transmitting the human immunodeficiency virus, cytomegalovirus, and hepatitis B virus to health care workers exposed to patients with AIDS and AIDS-related conditions. J. Infect. Dis. 156:1-8.

3. Moore, B. E., C. M. Flaitz, D. H. Coppenhaver, C. M. Nichols, G. D. Kalmaz, J. D. Bessman, M. W. Cloyd, D. P. Lynch, B. S. Prabhakar, and S. Baron. 1993. HIV recovery from saliva before and after dental treatment: inhibitors may have critical role in viral inactivation. J. Am. Dent. Assoc. 124:67-74.

4. Klein, R. S., J. A. Phelan, P. H. Freeman, M. S. Schable, G. H. Friedland, N. Trieger, and N. H. Steigbigel. 1988. Low occupational risk of human immunodeficiency virus infection among dental professionals. N. Engl. J. Med. 318:8690.

5. Fultz, P. N. 1986. Components of saliva inactivate human immunodeficiency virus. Lancet. ii: 1215.

6. Fox, P. C., A. Wolff, C.-K. Yeh, J. C. Atkinson, and B. J. Baum. 1988 Saliva inhibits HIV-1 infectivity. J. Am. Dent. Assoc. 116:635-637.

7. Fox, P. C., A. Wolff, C.-K. Yeh, J. C. Atkinson, and B. J. Baum. 1989. Salivary inhibition of HIV-1 infectivity: functional properties and distribution in men, women and children. J. Am. Dent. Assoc. 118:709-711.

8. Archibald, D. W., and G. A. Cole. 1990. In vitro inhibition of HIV-1 infectivity by human salivas. AIDS Res. Hum. Retroviruses. 6:1425-1432.

9. Coppenhaver, D. H., P. Sriyuktasuth-Woo, S. Baron, C. E. Barr, and M. N Qureshi. 1994. Correlation of nonspecific antiviral activity with the ability to isolate infectious HIV-1 from saliva. N. Engl. J. Med. 330:1314-1315.

10. Robinovitch, M. R., J. M. Iversen, and L. Resnick. 1993. Anti-infectivity activity of human salivary secretions toward human immunodeficiency virus. Crit. Rev. Oral Biol. Med. 4:455-459.

11. Yeh, C.-K., B. Handleman, P. C. Fox, and B. Baum. 1992. Further studies of salivary inhibition of HIV-1 infectivity. J. Acquired Immune Defic. Syndr. 9:898-903.
12. Malamud, D., C. Davis, P. Berthold, E. Roth, and H. Friedman. 1993. Human submandibular saliva aggregates HIV. AIDS Res. Hum. Retroviruses. 9:633-637.

13. Bergey, E. J., M.-I. Cho, M.-L. Hammarskjold, D. Rekosh, M. J. Levine, B. M. Blumberg, and L. G. Epstein. 1993. Aggregation of human immunodeficiency virus type 1 by human salivary secretions. Crit. Rev. Oral Biol. Med. 4:467-473.

14. Malamud, D., and H. M. Freidman. 1993. HIV in the oral cavity: virus, viral inhibitory activity, and antiviral antibodies: a review. Crit. Rev. Oral Biol. Med. 4:461-466.

15. Gartner, S., P. Markovits, D. M. Markovits, M. H. Kaplan, R. C. Gallo, and M. Popovic. 1986. The role of mononuclear phagocytes in HTLV-III/LAV infection. Science (Wash. DC). 233:215-219.

16. Meltzer, M. S., D. R., Skillman, P. J. Gomatos, D. C. Kalter, and H. E. Gendelman. 1990. Role of mononuclear phagocytes in the pathogenesis of human immunodeficiency virus. Annu. Rev. Immunol. 8:169-194.

17. Allen, J. B., H. L. Wong, P. Guyre, G. Simon, and S. M. Wahl. 1991. Circulating Fc $\delta$ RIII positive monocytes in AIDS patients. Induction by transforming growth factor beta. J. Clin. Invest. 87:1773-1779.

18. Allen, J. B., N. McCartney-Francis, P. D. Smith, G. Simon, S. Gartner, L. M. Wahl, M. Popovic, and S. M. Wahl. 1990. Expression of interleukin 2 receptors by monocytes from patients with acquired immunodeficiency syndrome and induction of monocyte interleukin 2 receptors by human immunodeficiency virus in vitro. J. Clin. Invest. 85:192-199.

19. Szebeni, J., S. M. Wahl, M. Popovic, L. M. Wahl, S. Gartner, R. L. Fine, U. Skaleric, and J. N. Weinstein. 1989. Dipyridamole potentiates the inhibition by 3 '-azido-3'deoxythymidine and other dideoxynucleosides of human immunodeficiency virus replication in monocyte/macrophages. Proc. Natl. Acad. Sci. USA 86:3842-3846.

20. Thompson, R. C., and K. Ohlsson. 1986. Isolation, properties, and complete amino acid sequence of human secretory leukocyte protease inhibitor, a potent inhibitor of leukocyte elastase. Proc. Natl. Acad. Sci. USA 83:6692-6696.

21. Wahl, L. M., I. M. Katona, R. L. Wilder, C. C. Winter, B. Haraoui, I. Scher, and S. M. Wahl. 1984. Isolation of human mononuclear cell subsets by counterflow centrifugal elutriation. I. Characterization of B lymphocyte, T lymphocyte and monocyte-enriched fractions by flow cytometric analysis. Cell. Immunol. 85:373-383.

22. Wahl, S. M., H. Wong, J. B. Allen, and L. R. Ellingsworth. 1990. Antagonistic and agonistic effects of transforming growth factor $\beta$ and IL-1 in rheumatoid arthritis. J. Immunol. 145:2514-2519.

23. Eisenberg, S. P., K. K. Hale, P. Heimdal, and R. C. Thompson. 1990. Location of the protease-inhibitory region of secretory leukocyte protease inhibitor. J. Biol. Chem. 265:7976-7981.

24. Finberg, R. W., S. M. Wahl, J. B. Allen, G. Soman, T. B. Strom, J. R. Murphy, and J. C. Nichols. 1991. Selective elimination of HIV-1-infected cells with an interleukin-2 receptor-specific cytotoxin. Science (Wash. DC). 252:17031705.

25. Wahl, S. M., J. B. Allen, S. Gartner, J. M. Orenstein, M. Popovic, D. E. Chenoweth, L. O. Arthur, W. L. Farrar, and L. M. Wahl. 1989. HIV-1 and its envelope glycoprotein down-regulate chemotactic ligand receptors and chemotactic function of peripheral blood monocytes. J. Immunol. 142:3553-3559.

26. Malmqvist, M. 1993. Biospecific interaction analysis using biosensor technology. Nature (Lond.). 361:186-187.

27. VanCott, T. C., L. D. Loomis, R. R. Redfield, and D. L. Birx. 1992. Realtime biospecific interaction analysis of antibody reactivity to peptides from the envelope glycoprotein, gp160, of HIV-1. J. Immunol. Methods. 146:163-176.

28. Brigham-Burke, M., J. R. Edwards, and D. J. O'Shannessy. 1992. Detection of receptor-ligand interactions using surface plasmon resonance: model studies employing the HIV-1 gp120/CD4 interaction. Anal. Biochem. 205:125-131.

29. Lamkin, M. S., and F. G. Oppenheim. 1993. Structural features of salivary function. Crit. Rev. Oral Biol. Med. 4:251-259.

30. Barr, C. E., L. K., Miller, M. R. Lopez, T. S. Croxson, S. A. Schwartz, H. Denman, and R. Jandorek. 1992. Recovery of infectious HIV-1 from whole saliva. Blood proves more likely virus transmitter. J. Am. Dent. Assoc. 123:3745.

31. Yeung, S. C. H., F. Kazazi, C. C.-M. Randle, R. C. Howard, N. Rizvi, J. C. Downie, B. J. Donovan, D. A. Cooper, H. Sekine, D. E. Dwyer, and A. L. Cunningham. 1993. Patients infected with human immunodeficiency virus type 1 have low levels of virus in saliva even in the presence of periodontal disease. $J$. Infect. Dis. 167:803-809.

32. Coppenhaver, D. H., J. L. Baron, M. L. McKerlie, J. Sobados, and S. Baron. 1984. Size and stability of a naturally occurring virus inhibitor. Antimicrob. Agents Chemother. 25:646-649.

33. Baron, S., D. Niesel, I. P. Singh, L. McKerlie, J. Poast, A. Chopra, G. Antonelli, F. Dianzani, and D. H. Coppenhaver. 1989. Recently described innate broad spectrum virus inhibitors. Microb. Pathog. 7:237-247.

34. Kramps, J. A., C. Franken, and J. G. Dijkman. 1984. ELISA for quantita- 
tive measurement of low-molecular-weight bronchial protease inhibitor in human sputum. Am. Rev. Respir. Dis. 129:959-963.

35. Stetler, G., M. T. Brewer, and R. C. Thompson. 1986. Isolation and sequence of a human gene encoding a potent inhibitor of leukocyte proteases. Nucleic Acids Res. 14:7883-7896.

36. Lucey, E. C., P. J. Stone, D. E. Ciccolella, R. Breuer, T. G. Christensen, R. C. Thompson, and G. L. Snider. 1990. Recombinant human secretory leukocyte-protease inhibitor: in vitro properties, and amelioration of human neutrophil elastase-induced emphysema and secretory cell metaplasia in the hamster. J. Lab. Clin. Med. 115:224-232.

37. Stromatt, S. C. 1993. Secretory leukocyte protease inhibitor in cystic fibrosis. Agents Actions Suppl. 42:103-110.

38. Ashorn, P. A., E. A. Berger, and B. Moss. 1990. Human immunodeficiency virus envelope glycoprotein/CD4-mediated fusion of nonprimate cells with human cells. J. Virol. 64:2149-2156.

39. Clapham, P. R., D. Blanc, and R. A. Weiss. 1991. Specific cell surface requirements for the infection of CD4-positive cells by human immunodeficiency virus types 1 and 2 and by simian immunodeficiency virus. Virology. 181:703715.

40. Callebout, C., B. Krust, E. Jacotot, and A. G. Hovanessian. 1993. T cell activation antigen, CD26, as a cofactor for entry of HIV in CD4+ cells. Science (Wash. DC). 262:2045-2050.

41. Broder, C. C., O. Nussbaum, W. G. Gutheil, W. W. Bachovchin, and E. A. Berger. 1994. CD26 antigen and HIV fusion? Science (Wash. DC). 264:1156-1159.

42. Moore, J. P., and P. L. Nara. 1991. The role of the V3 loop of gp120 in HIV infection. AIDS. 5(Suppl. 2):S21-S33.

43. Clements, G. J., M. J. Price-Jones, P. E. Stephens, C. Sutton, T. F. Schulz, P. R. Clapham, J. A. McKeating, M. O. McClure, S. Thomson, M. Marsh, J. Kay, R. A. Weiss, and J. P. Moore. 1991. The V3 loops of the HIV-1 and HIV-2 surface glycoproteins contain proteolytic cleavage sites: a possible function in viral fusion? AIDS Res. Hum. Retroviruses. 7:3-16.

44. Hattori, T., A. Koito, K. Takatsuki, H. Kido, and N. Katunuma. 1989. Involvement of tryptase-related cellular protease (s) in human immunodeficiency virus type 1 infection. FEBS (Fed. Eur. Biochem. Soc.) Lett. 248:48-52.

45. Ryser, H. J.-P., E. M. Levy, R. Mandel, and G. J. DiSciullo. 1994. Inhibition of human immunodeficiency virus infection by agents that interfere with thiol-disulfide interchange upon virus-receptor interaction. Proc. Natl. Acad. Sci. USA. 91:4559-4563.

46. Campbell, E. J., E. K. Silverman, and M. A. Campbell. 1989. Elastase and cathepsin G of human monocytes. J. Immunol. 143:2961-2968.

47. Avril, L.-E., M. C. Martino-Ferrer, G. Pignede, M. Seman, and F. Gauthier. 1994. Identification of the U-937 membrane-associated proteinase interacting with the V3 loop of HIV-1 gp120 as cathepsin G. FEBS (Fed. Eur. Biochem. Soc.) Lett. 345:81-86.

48. Ueno, R., and S. Kuno. 1987. Dextran sulfate, a potent anti-HIV agent in vitro having synergism with zidovudine. Lancet. i:1379.

49. Mitsuya, H., D. J. Looney, S. Kuno, R. Ueno, F. Wong-Staal, and S. Broder. 1988. Dextran sulfate suppression of viruses in the HIV family: inhibition of virion binding to $\mathrm{CD}^{+}$cells. Science (Wash. DC). 240:646-649.

50. Gillissen, A., P. Birrer, N. G. McElvaney, R. Buhl, C. Vogelmeier, R. F. Hoyt, Jr., R. C. Hubbard, and R. G. Crystal. 1993. Recombinant secretory leukoprotease inhibitor augments glutathione levels in lung epithelial lining fluid. $J$. Appl. Physiol. 75:825-832.

51. Roederer, M., F. J. T. Staal, P. A. Raju, S. W. Ela, L. A. Herzenberg, and L. A. Herzenberg. 1990. Cytokine-stimulated human immunodeficiency virus replication is inhibited by $\mathrm{N}$-acetyl-L-cysteine. Proc. Natl. Acad. Sci. USA. 87:4884-4888.

52. Kalebic, T., A. Kinter, G. Poli, M. E. Anderson, A. Meister, and A. S. Fauci. 1991. Suppression of human immunodeficiency virus expression in chronically infected monocytic cells by glutathione, glutathione ester, and $\mathrm{N}$-acetylcysteine. Proc. Natl. Acad. Sci. USA. 88:986-990.

53. Miller, C. J., N. J. Alexander, S. Sutjipto, A. L. Lackner, A. Gettie, A. G. Hendrickx, L. J. Lowenstine, M. Jennings, and P. A. Marx. 1989. Genital mucosal transmission of simian immunodeficiency virus: animal model for heterosexual transmission of human immunodeficiency virus. J. Virol. 63:4277-4284.

54. Sutjipto, S., N. C. Pedersen, C. J. Miller, M. B. Gardner, C. M. Hanson, A. Gettie, M. Jennings, J. Higgins, and P. A. Marx. 1990. Inactivated simian immunodeficiency virus vaccine failed to protect rhesus macaques from intravenous or genital mucosal infection but delayed disease in intravenously exposed animals. J. Virol. 64:2290-2297.

55. Lazzarin, A., A. Saracco, M. Musicco, and A. Nicolosi. 1991. Man to woman sexual transmission of the human immunodeficiency virus. Arch. Intern. Med. 151:2411-2416. 